\title{
Simulation in nursing baccalaureate courses of Brazilian educational institutions
}

\author{
O uso da simulação em cursos de bacharelado em enfermagem de instituições de ensino brasileiras \\ Simulación en cursos de bachillerato de enfermería de instituciones educativas brasileñas
}

\section{Simulación en cursos de bachillera to

\begin{tabular}{r}
\hline Eduardo Fuzetto Cazañas' \\
ORCID: 0000-0002-9711-501X \\
Rosana Leal do Prado"' \\
ORCID: 0000-0002-5897-2799 \\
Tayomara Ferreira Nascimento' \\
ORCID: 0000-0001-8814-6159 \\
Silvia Franco da Rocha Tonhom'"' \\
ORCID: 0000-0001-7522-2861 \\
Maria José Sanches Marin' \\
ORCID: 0000-0001-6210-6941
\end{tabular}

'Universidade Estadual Paulista. Botucatu, São Paulo, Brazil. "Universidade do Oeste Paulista. Presidente Prudente,

São Paulo, Brazil.

I" Faculdade de Medicina de Marília. Marília, São Paulo, Brazil.

How to cite this article:

Cazañas EF, Prado RL, Nascimento TF, Tonhom SFR, Marin MJS. Simulation in nursing baccalaureate courses of Brazilian educational institutions. Rev Bras Enferm. 2021;74(Suppl 5):e20190730. https://doi.org/10.1590/0034-7167-2019-0730

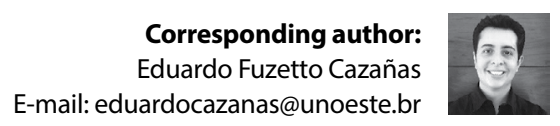

EDITOR IN CHIEF: Dulce Barbosa ASSOCIATE EDITOR: Elisabete Salvador

Submission: $01-20-2020$

Approval: 11-01-2020

\begin{abstract}
Objective: to characterize simulation practices in nursing courses in Brazil, considering the attributes developed, facilities, and challenges encountered. Methods: this is a crosssectional and descriptive study, with a quantitative approach. Ninety-one coordinators of undergraduate courses participated in the study. An electronic questionnaire was used with open- and closed-ended questions. Results: the most used simulation modality is Specific Skills. Private courses and courses with integrated curricula most often use High Fidelity Simulation. Understanding the mobilization of affective attributes is still insufficient. Conclusion: it is important that undergraduate course managers are aware and take ownership of the elements that permeate simulation and invest to create a favorable environment for its effectiveness. Descriptors: Education, Nursing, Baccalaureate; Teaching; Students, Nursing; Patient Simulation; High Fidelity Simulation Training.
\end{abstract}

\section{RESUMO}

Objetivo: Caracterizar práticas de simulação nos Cursos de Enfermagem do Brasil, considerando os atributos desenvolvidos. Métodos: Estudo transversal e descritivo, com abordagem quantitativa. Participaram do estudo 91 coordenadores de cursos de graduação. Foi utilizado questionário eletrônico com questões abertas e fechadas. Resultados: A modalidade de simulação mais utilizada foi a de Habilidades Específicas. Cursos privados e os cursos com currículos integrados utilizam com maior frequência a Simulação de Alta Fidelidade. A compreensão sobre a mobilização dos atributos afetivos ainda é insuficiente. Conclusão: $E$ importante que os gestores dos cursos de graduação sejam sensibilizados e apropriem-se dos elementos que permeiam a realização da simulação e invistam para oportunizar um ambiente favorável para sua efetivação.

Descritores: Bacharelado em Enfermagem; Ensino de Enfermagem; Realidade Virtual; Simulação de Paciente; Treinamento com Simulação de Alta Fidelidade.

\section{RESUMEN}

Objetivo: caracterizar las prácticas de simulación en cursos de enfermería en Brasil considerando los atributos desarrollados, las instalaciones y los desafíos encontrados. Métodos: estudio transversal y descriptivo, con enfoque cuantitativo. En el estudio participaron 91 coordinadores de cursos de pregrado. Se utilizó un cuestionario electrónico con preguntas abiertas y cerradas. Resultados: la modalidad de simulación más utilizada fue Habilidades Específicas. Los cursos privados y los cursos con planes de estudio integrados suelen utilizar la Simulación de Alta Fidelidad. La comprensión de la movilización de atributos afectivos es aún insuficiente. Conclusión: es importante que los gerentes de los cursos de pregrado estén sensibilizados, apropiándose de los elementos que permean la simulación e invirtiendo para crear un entorno propicio para su efectividad.

Descriptores: Bachillerato em Enfermería; Educación em Enfermería; Realidad Virtual; Simulación de Paciente; Enseñanza Mediante Simulación de Alta Fidelidad. 


\section{INTRODUCTION}

Higher Education Institutions (HEls) that train nurses have complex challenges to implement the proposed changes, in order to provide training based on praxis. For this to occur, curricular flexibility is necessary, with the Unified Health System (Sistema Único de Saúde) as a priority setting and using innovative teaching methodologies, aiming at transforming the current health care setting ${ }^{(1-3)}$.

In this perspective, nursing courses have sought to modify their curricular structure through new pedagogical arrangements expressed by using more participative teaching and learning strategies, integration between disciplines and insertion in diversified professional practice settings since early grades ${ }^{(4)}$. Among the strategies used to promote critical and reflective teaching, simulation in its different modalities has been the most used, followed by problematizing education with emphasis on Problem-Based Learning and clinical case studies.

Thus, simulation is gaining prominence for enhancing the teaching and learning process in a risk-free environment for users ${ }^{(5)}$. In the practice of teaching in nursing courses, different types of simulation can be found, which are given different names, and in the present study the definitions proposed by Brandão, Colares, and Marin are considered ${ }^{(1,6)}$ : Specific Skills: mannequins for training specific procedures such as otoscopy, cardiac auscultation, bladder catheterization, among others. It does not necessarily use setting to contextualize the situation. Standardized Patient: actors trained in simulation or trained students/real patients are used, being widely used for training in behavioral skills and student assessment ${ }^{(1,6)}$. High Fidelity Simulation: robots with advanced technology that reproduce physiological situations, very close to reality. Virtual Reality: simulation using computer graphics to replicate procedures. Hybrid Simulation: association between a standardized patient and a mannequin of technical skills $s^{(1,6)}$.

Since the 1990s, the importance of simulation has been demonstrated, because in addition to favoring demonstration, it enables developing the process of knowing how to do something. Simulation makes it possible to develop "knowledge", represented by cognitive learning; "Knowing how", which indicates the ability to apply knowledge in a given context; "Showing how", where learners are challenged to demonstrate what they know; "Doing", which is expressed by practice in real situations $\mathrm{s}^{(1,7)}$.

Simulation also stands out for meeting the worldwide discussion on patient safety, as it allows students to learn from mistakes and malpractices in a place protected from risks to health system users.

The World Health Organization (WHO) proposes in 2004 the World Alliance for Patient Safety, which was incorporated by nursing in 2005 with the creation of the International Network for Nursing and Patient Safety. In this regard, there is a need for curricular organization in order to ensure contents that provide learning about patient safety, suggesting even practical learning in controlled environments (simulation) ${ }^{(1,8)}$.

A literature review revealed that the most used simulation modality in nursing education is simulation using Mannequins, followed by Patient Simulation, Virtual Simulation, and Hybrid Simulation ${ }^{(5)}$. Another study presents the most used Virtual Simulation modality, followed by Patient Simulation and Simulation of Specific Skills with low-fidelity mannequin use ${ }^{(9)}$.
Simulation, according to studies, has involved both technical training and the development of clinical reasoning (cognitive attribute), communication (affective attribute) and interdisciplinary training. Other recognized aspects are strong student satisfaction and improved self-confidence ${ }^{(10-11)}$. However, weaknesses are identified as the lack of professors' pedagogical preparation, the large amount of time spent in carrying them out, lack of physical space and financial resources ${ }^{(5-9)}$. Moreover, there is a need to adapt its insertion in the curriculum, the understanding of professors in its use and advances in research on it ${ }^{(12-13)}$.

Namely, Brazil, in comparison with other countries, is still lacking in publications on the teaching strategies used; however, it is emphasized the need to advance in nursing training through changes in pedagogical processes ${ }^{(9-14)}$. Considering the relevance of simulation in nursing training and considering that little is known about how this strategy has been developed in Brazil, in the present study, there is a question: how do nursing courses use simulation?

\section{OBJECTIVE}

To characterize simulation practices in nursing courses in Brazil, considering the attributes developed, facilities, and challenges encountered.

\section{METHODS}

\section{Ethical aspects}

The study respects the ethical precepts provided for by Resolution 466/2012 ${ }^{(15)}$ of the Brazilian National Health Council (Conselho Nacional de Saúde). The project was approved by the Ethics Committee on Research with Human Beings receiving approval on May 5, 2017.

\section{Design, period, and place of study}

This is a cross-sectional and descriptive research, with a quantitative and qualitative approach ${ }^{(16)}$, using the references from the EQUATOR network, and the Strengthening the Reporting of Observational studies in Epidemiology initiative (STROBE) ${ }^{(17)}$. This study was carried out between February 2018 to March 2019, the setting is represented by undergraduate nursing courses in Brazil.

\section{Sample; inclusion and exclusion criteria}

To carry out the study, existing nursing courses in Brazil were identified through http://emec.mec.gov.br ${ }^{(18)}$. In the e-MEC system, there were 1,050 in-class courses in activity of baccalaureate/ license for teaching, offered by $791 \mathrm{HEls}$, of which $14.76 \%$ are offered free of charge by public institutions.

This study included nursing courses with Preliminary Course Concept (CPC) three, four and five among the private colleges, and these data were obtained from the evaluation carried out in $2014^{(19)}$. Concerning public HEls, all institutions were included, regardless of the assigned CPC concept, as many do not have the obligation to submit to the Ministry's assessment criteria, considering that they 
are monitored by the State Education Council (Conselho de Estadual de Saúde) courses with a CPC lower than three or that had not yet been assessed by MEC were excluded. With such characteristics, 372 courses from private 155 public institutions were found. Of the 527 invited courses, 91 nursing courses responded and participated in the research, 60 from private HEls and 31 public HEls.

\section{Study protocol}

After defining the 527 courses that would be part of this study, coordinators' emails were located through the homepages of the respective courses. In possession of these data, contact was made via e-mail and self-administered questionnaires were sent via the Web.

After defining the 527 courses that would be part of this study, the coordinators'e-mail was located through the homepages of the respective courses. In possession of these data, contact was made via e-mail and self-administered questionnaires were sent via the Web.

A login and password were generated for each $\mathrm{HEI}$. The questionnaire was triggered automatically at a monthly frequency from February to October 2018, biweekly from November 2018 to January 2019 and weekly from February to 03/31/2019, the deadline established to complete the data collection. The coordinators who participated in the survey answered the questionnaire after reading and accepting the Informed Consent Form.

Data obtained were coded in a Microsoft Office Excel 2010 spreadsheet.

\section{Analysis of results, and statistics}

Data were submitted to descriptive statistical analysis and presented in the form of absolute and relative frequency, means, according to the nature of the variable. The outcome variable was considered the simulation modality categorized into five items: Specific Skills; Standardized Patient, High Fidelity; Virtual Reality and Hybrid Simulation. Meanwhile, independent variables were attributes mobilized by simulation (cognitive, affective and psychomotor) and variables related to the institution's profile, operating time, type of curriculum, public or private character and training of coordinators and attributes.

To test the associations between outcome (simulation mode) and independent variables (institution profile), chi-square test and Cramér's $V$ test were used, which provide a measure of the degree of association between two categorical variables.

As for association between outcome (simulation methods) and independent variables (cognitive, affective, and psychomotor attributes), the chi-square test was used. To that end, we considered only the HEls that reported using this modality. To perform the test, the categories of the attributes were dichotomized, as well as simulation modalities, seeking to identify whether the presence of the attribute is statistically significant, given the simulation modality ${ }^{(20)}$. Statistical analyzes were performed using software $R$, with a significance level of $5 \%$ ( $p$ value $<0.05$ ).

\section{RESULTS}

Thus, 91 coordinators of nursing courses participated in the research, which corresponds to $17.3 \%$ of the total of invited courses.
Figure 1 shows the map of Brazil with the response rate by region and considering the number of courses invited to participate in the survey, the south had the highest participation, followed by center-western, southeastern, northeastern and northern Brazil.

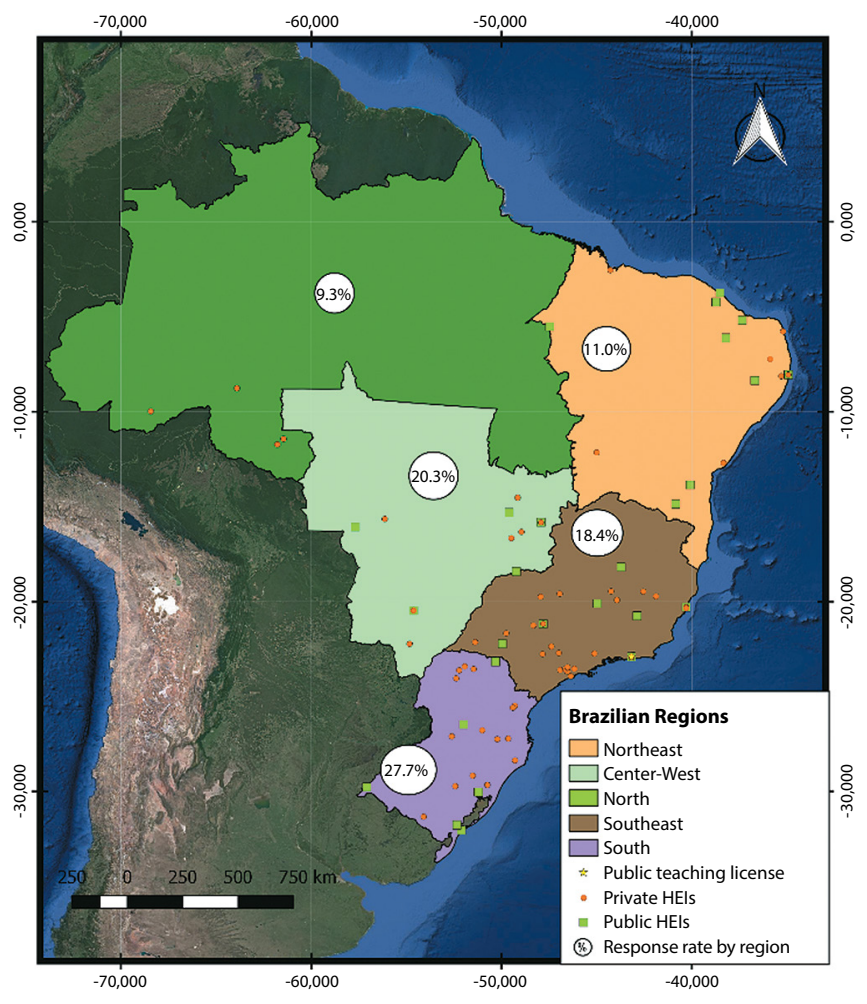

Figure 1 - Distribution of participating public and private Higher Education Institutions, Botucatu, São Paulo, Brazil, 2019

Table 1 shows the predominance of private institutions, with a baccalaureate's degree, which have been in operation for more than 10 years, use the curriculum organized by subjects and have a duration of five years. As for profession, 89 coordinators are nurses, one is biomedical and one did not answer. Regarding training (graduate), most of them have a master's and doctorate degree. The courses on mean have 18.7 professional nurses with a minimum of three and a maximum of 85 , most of whom dedicate thirty hours or more to graduation.

Among the 88 coordinators who indicated using simulation in course development, Specific Skills Simulation is referred to in its entirety, followed by Standardized Patient, Hybrid Simulation, High fidelity Simulation and lastly Virtual Reality with only 10 courses.

There is a statistically significant difference between High Fidelity Simulation in relation to the form of curricular organization and type of institution, indicating that this modality is proportionally more used in courses that use the integrated curriculum and in private institutions. As for the other modalities, there was no statistically significant difference between the variables analyzed.

Table 3's results demonstrate that in Standardized Patient and Virtual Reality simulations it is not possible to state that there is understanding on the part of the coordinators as to the affective attribute mobilization ( $p>0.05$ ). Although it is not possible to state from a statistical point of view that there is an understanding of the mobilization of the cognitive attribute by simulation of Virtual 
Table 1 - Characteristics of undergraduate courses and insertion of simulation in curriculum, Botucatu, São Paulo, Brazil,2019

\begin{tabular}{|c|c|c|}
\hline \multicolumn{3}{|l|}{ Type of institution } \\
\hline Private & 59 & $64.8 \%$ \\
\hline Public & 32 & $35.2 \%$ \\
\hline \multicolumn{3}{|l|}{ Modality } \\
\hline Baccalaureate & 90 & $98.9 \%$ \\
\hline License for teaching & 1 & $1.1 \%$ \\
\hline \multicolumn{3}{|l|}{ Course running time } \\
\hline $6-10$ years & 13 & $14.3 \%$ \\
\hline More than 10 years & 77 & $84.6 \%$ \\
\hline No answer & 1 & $1.1 \%$ \\
\hline \multicolumn{3}{|l|}{ Curriculum type } \\
\hline By course & 61 & $67.0 \%$ \\
\hline Interdisciplinary/integrate & 22 & $24.2 \%$ \\
\hline By modules & 4 & $4.4 \%$ \\
\hline Another organization & 3 & $3.3 \%$ \\
\hline No answer & 1 & $1.1 \%$ \\
\hline \multicolumn{3}{|l|}{ Course length } \\
\hline 4 years & 13 & $14.3 \%$ \\
\hline 5 years & 76 & $83.5 \%$ \\
\hline No answer & 2 & $2.2 \%$ \\
\hline \multicolumn{3}{|l|}{ Profession of coordinators } \\
\hline Nurses & 89 & $97.8 \%$ \\
\hline Biomedical & 1 & $1.1 \%$ \\
\hline No answer & 1 & $1.1 \%$ \\
\hline \multicolumn{3}{|l|}{ Academic degree of coordinators } \\
\hline Post-doctoral degree & 4 & $4.4 \%$ \\
\hline Doctoral degree & 33 & $36.3 \%$ \\
\hline Master's degree & 44 & $48.4 \%$ \\
\hline Specialist & 9 & $9.9 \%$ \\
\hline No answer & 1 & $1.1 \%$ \\
\hline \multicolumn{3}{|l|}{ Faculty nurses } \\
\hline \multicolumn{3}{|l|}{ Number of nurse educators } \\
\hline Up to 10 nurses & 37 & $40.7 \%$ \\
\hline 11 to 20 nurses & 24 & $26.4 \%$ \\
\hline 21 to 30 nurses & 15 & $16.5 \%$ \\
\hline Above 30 nurses & 14 & $15.4 \%$ \\
\hline No answer & 1 & $1.1 \%$ \\
\hline \multicolumn{3}{|l|}{ Workload/professor } \\
\hline Less than 10 hours: & 79 & $4.4 \%$ \\
\hline 10 to 20 hours: & 353 & $19.7 \%$ \\
\hline 20 to 30 hours: & 218 & $12.1 \%$ \\
\hline 30 to 40 hours: & 714 & $39.8 \%$ \\
\hline More than 40 hours: & 432 & $24.1 \%$ \\
\hline Total: & 1.796 & $100 \%$ \\
\hline \multicolumn{3}{|c|}{ Simulated practice in the course } \\
\hline Yes & 88 & $96.7 \%$ \\
\hline No & 3 & $3.3 \%$ \\
\hline \multicolumn{3}{|l|}{ Simulation modality } \\
\hline Specific skills & 88 & $100 \%$ \\
\hline Standardized patient & 59 & $67.0 \%$ \\
\hline High fidelity & 29 & $33.0 \%$ \\
\hline Virtual reality & 10 & $11.4 \%$ \\
\hline Hybrid & 46 & $52.3 \%$ \\
\hline
\end{tabular}

Reality ( $p=0.058)$, it is believed that this data is a reflection of the low number of HEls that use this method.

\section{DISCUSSION}

We sought to characterize simulation use in nursing courses in Brazil. The southeast and northeast are those regions that have more nursing courses; in the southeast, due to higher population density and higher concentration of income; in the northeast, because it was privileged by the restructuring program of federal universities. The south, although considered industrially developed, has a small number of nursing courses compared to other regions. The center-west, possibly due to the fact that it is still a developing region, expanded in a smaller proportion of the number of courses. In the north, it appears to be the least equipped with physical and economic resources to enable the growth of courses in line with the population's health needs ${ }^{(21-23)}$.

Thus, important regional differences in the distribution of nursing courses in Brazil stand out, with the majority of them concentrated in large centers, leaving a gap in meeting the needs of more remote regions and lacking economic resources. In recent decades, neoliberal policy has led to an increase in the number of private institutions ${ }^{(23)}$, requiring advances in their qualification and improvement, through investments in educational technologies and professor qualification.

The data in the present study indicate advances in the training of nurses as there are courses developed over five years. This allows for greater maturity and the possibility of greater contact with professional practice, and the fact that it includes simulation as an activity protected from risks to users. Moreover, most coordinators have a positive influence on nursing training and master's or doctorate courses.

Concerning the profile of coordinators, the results of this work are in line with research carried out in the states of São Paulo and in Minas Gerais ${ }^{(24-25)}$, most of which have a master's or doctorate. Coordinators holding a doctorate degree showed a higher perception of educational competence when compared to other degrees ${ }^{(24)}$.

A course coordinator needs to understand the factors involved in planning and organizing simulation, which includes defining the physical area, detailed setting loyalty, material resource allocation and preparation of professors for the activity, in addition to making time available in the curriculum so that the same occurs satisfactorily ${ }^{(24-25)}$.

Table 2 - Association between simulation modalities and the profile of undergraduate courses, Botucatu, São Paulo, Brazil, 2019

\begin{tabular}{|c|c|c|c|c|c|c|c|c|c|c|}
\hline \multirow[t]{2}{*}{ Variables } & \multicolumn{2}{|c|}{ Skills } & \multicolumn{2}{|c|}{ Patient } & \multicolumn{2}{|c|}{ Simulation modalities } & \multicolumn{2}{|c|}{ Virtual } & \multicolumn{2}{|c|}{ Hybrid } \\
\hline & n (\%) & $p$ value & n (\%) & $p$ value & n (\%) & $p$ value & n (\%) & $p$ value & $n(\%)$ & $p$ value \\
\hline Running time & & 0.909 & & 0.355 & & 0.542 & & 0.339 & & 0.469 \\
\hline 6-10 years & $13(14.9)$ & & $9(15.3)$ & & $3(10.3)$ & & $3(30.0)$ & & $8(17.4)$ & \\
\hline more than 10 years & 73 (83.9) & & $50(84.7)$ & & $26(89.7)$ & & $7(70.0)$ & & $37(80.4)$ & \\
\hline N/A & $1(1.1)$ & & $0(0.0)$ & & $0(0.0)$ & & $0(0.0)$ & & $1(2.2)$ & \\
\hline Curriculum & & 0.976 & & 0.600 & & $0.040^{*}$ & & 0.926 & & 0.146 \\
\hline Interdisciplinary/integrated & $22(25.3)$ & & $19(32.2)$ & & $11(37.9)$ & & $3(30.0)$ & & 15 (32.6) & \\
\hline Another organization & $2(2.3)$ & & $2(3.4)$ & & $2(6.9)$ & & $0(0.0)$ & & $1(2.2)$ & \\
\hline By subjects & $59(67.8)$ & & $37(62.7)$ & & $16(55.2)$ & & $7(70.0)$ & & $29(63.0)$ & \\
\hline By modules & $3(3.4)$ & & $1(1.7)$ & & $0(0.0)$ & & $0(0.0)$ & & $0(0.0)$ & \\
\hline N/A & $1(1.1)$ & & $0(0.0)$ & & $0(0.0)$ & & $0(0.0)$ & & $1(2.2)$ & \\
\hline Type of institution & & 0.469 & & 0.136 & & $0.049^{* *}$ & & 0.318 & & 0.449 \\
\hline Private & $30(34.5)$ & & $17(28.8)$ & & $14(48.3)$ & & $2(20.0)$ & & $14(30.4)$ & \\
\hline Pública & $57(65.5)$ & & $42(71.2)$ & & $15(51.7)$ & & $8(80.0)$ & & $32(69.6)$ & \\
\hline
\end{tabular}


Table 3 - Understanding of the coordinator in relation to the attribute mobilized by simulation modality, Botucatu, São Paulo, Brazil, 2019

\begin{tabular}{|c|c|c|c|c|c|c|c|}
\hline \multirow{3}{*}{ Simulation } & \multirow{3}{*}{ (n) } & \multicolumn{6}{|c|}{ Attributes } \\
\hline & & \multicolumn{2}{|c|}{ Cognitive/Knowledge } & \multicolumn{2}{|c|}{ Psychomotor/Skill } & \multicolumn{2}{|c|}{ Affective/Attitudinal } \\
\hline & & n (\%) & $p$ value & n (\%) & $p$ value & n (\%) & $p$ value \\
\hline Skills & (88) & $80(90.9)$ & $<0.001$ & $82(93.2)$ & $<0.001$ & $56(63.6)$ & 0.284 \\
\hline Patient & (59) & $55(93.2)$ & 0.001 & $52(88.1)$ & $<0.001$ & $27(45.8)$ & 0.515 \\
\hline High fidelity & (29) & $27(93.1)$ & $<0.001$ & $28(96.6)$ & $<0.001$ & $23(79.3)$ & 0.001 \\
\hline Virtual & (10) & $8(80.0)$ & 0.058 & $9(90.0)$ & 0.011 & $4(40.0)$ & 0.527 \\
\hline Hybrid & (46) & $43(93.5)$ & $<0.001$ & $39(84.8)$ & $<0.001$ & $39(84.8)$ & $<0.001$ \\
\hline
\end{tabular}

Currently, HEls face several challenges, due to the significant increase in the rate of university students. In 1964, there was a rate of $1.5 \%$ of the population enrolled $(142,386)$, in 2011 it was already $28.2 \%(6,739,689)$ enrolled ${ }^{(26)}$. In 2018 , a contingent of 8.45 million people started an undergraduate course in higher education. From 2008 to 2018, there was an increase of $44.6 \%$ in the number of enrolled ${ }^{(27)}$.

The Brazilian National Education Plan (PNE - Plano Nacional de Educação) (2014-2024) brought as a target for the period, an increase of $50 \%$ in the number of enrolled/population for higher education, which will possibly be achieved. This same law that institutes PNE mentions that this increase must be carried out "keeping the quality of the offer ensured"; however, HEls have difficulties in meeting this demand(28).

Among others, there are challenges in maintaining an adequate number of teaching staff with a full-time doctoral degree and establishing new part-time professor hiring arrangements to meet the demand. Other factors that weigh when deciding to invest in teaching staff are due to: important asymmetries between the different regions of the country; the increase in distance learning courses, estimated to grow $880 \%$ by 2020 ; the maintenance of financial resources equivalent to $7 \%$ of the Gross Domestic Product (GDP). Several simulations indicate that the percentage that would make PNE principles, objectives and targets viable $\mathrm{e}^{(28)}$ would be $10 \%$ of GDP, in order to guarantee an expansion that would ensure the quality of education ${ }^{(26)}$.

To qualify a professional with a generalist profile, critical profile who is able to recognize the health needs of the population, the proposal for curricular reorganization becomes a central element, in the sense of breaking with a traditional disciplinary and disjointed curriculum from reality. Among the different curricular designs, it is understood that the integrated curriculum that uses active teaching and learning strategies has greater potential to qualify a professional with the desired profile ${ }^{(4,29-30)}$. However, most courses still maintain the curriculum organized by subject.

Difficulties inherent in the change process seem to permeate curricular reorganization, and it is possible that courses will encounter difficulties, since it is a movement that involves new ways of acting and thinking about teaching and health care. Even facing the different forms of curricular organization, simulation modalities permeate all. Simulation is a powerful teaching strategy that has the capacity to boost the development of cognitive, affective and psychomotor attributes, contributing to the improvement of professional performance and competence ${ }^{(31-32)}$.

The notion of professional competence can be inferred through the observation of student performance in simulated situations, resulting in a protected learning process, enabling the construction of new knowledge oriented towards professional excellence ${ }^{(32-33)}$.

In this study, there was a predominance of Specific Skills Simulation, which has been used since the beginning of the $20^{\text {th }}$ century in the United States and Brazil. Having as main purpose developing the psychomotor attribute ${ }^{(34)}$, it must be used in a careful and complementary way, since, by itself, it does not contemplate the contextualization and the articulation of cognitive and affective attributes.

Simulation, through a Standardized Patient, is the one that most closely matches reality and favors the articulation of cognitive, affective and psychomotor attributes. It can be performed by a professional actor or a properly trained person. Its use requires planning, involving everything from preparing the script and training the actors, to the architectural details to raise the reliability of a real setting. Usually in this modality after simulation, debriefing is carried out, which despite different concepts and techniques, in general can be understood as a space for formative assessment where students express their perceptions about simulation, identify potentials and challenges to be overcome and professors play a role in mediating this process. Among the challenges is the time that needs to be spent training amateur actors and/or hiring professional actors ${ }^{(10,35)}$.

Some institutions recruit actors through hiring, and despite the financial resources spent, this work logic enhances the learning process, since they are able to standardize simulations ${ }^{(10,30,36)}$.

Another modality that stands out is High Fidelity Simulation, as it allows the reproduction and handling of changes in physiology that would not be possible/viable with human beings. This simulation is accompanied by debriefing and favors the articulation of cognitive, affective and psychomotor attributes. Although this modality is very powerful for the integration of attributes, it can be underused when only Skills Simulation is performed, i.e., for technical teaching ${ }^{(5,9-12)}$. Another challenge for developing this simulation modality is the financial investment required to acquire robots and software, since the cost is high ${ }^{(37)}$. Furthermore, there is a need for investment in training professors to handle the software of High Fidelity mannequins ${ }^{(5,9-12,37)}$.

Virtual Reality can also be used in order to articulate the cognitive, affective and psychomotor attributes, or even to emphasize or foster an attribute, i.e., it can constitute a clinical and complex setting. It is a powerful modality, but still in small use ${ }^{(5,38)}$. This data is consistent with the results of this research, since few use Virtual Reality. One explanation may be the high cost and the need to hire professionals with training in Information Technology with experience in software development in health education. 
Finally, the modality called Hybrid Simulation is powerful due to the fact that it makes the connection between Standardized Patient and Mannequins ${ }^{(6,34,39)}$. In this study, this is the third most used modality and due to the fact that it associates the human actor with low, medium and high fidelity mannequins, it is subject to the same difficulties previously mentioned.

The results found in this research call attention to the affective attribute. According to coordinators' views, this is the attribute least mobilized by simulation, except for Specific Skills Simulation, all others can mobilize this attribute, especially Standardized Patient simulation, because the simulator is a human and can interact through verbal and non-verbal expressions.

When considering that practice in the real world is an essential requirement for nursing training; however, in parallel, Patient Safety is an increasingly studied aspect, simulation is a strategy that, if well designed and conducted, allows students to experience a situation very close to reality, without putting patient safety at risk, preparing them so that when they arrive in real practice they will be safer and better able to interact and intervene on patients $s^{(5,8-10,34)}$.

\section{Study limitations}

Possible limitations are related to the sample size $\mathrm{n}(91)$, of a total of 527 courses invited to participate in the research, configuring a response rate of $17.26 \%$. It is noteworthy, however, the low adherence or incomplete responses in internet surveys is one of the main disadvantages, with response rate varying between 7 and 13\% ${ }^{(40-41)}$.

Another weakness is the impossibility of stating that there is no statistical difference between the influence of the coordinator's training in the different modalities. For that, it would be necessary to make another analysis, in which the different formations were compared with the types of modality used simultaneously and not individually.

\section{Contributions to nursing and health}

The present study reveals the simulation modalities used in Brazil, in public and private institutions, as well as powers and challenges that need to be overcome to improve simulation practice as a teaching and learning strategy in nursing courses.

\section{CONCLUSION}

In this study, it was possible to verify that $100 \%$ of courses use Simulation of Specific Skills, followed by Standardized Patient Simulation, Hybrid Simulation, High Fidelity Simulation and finally Virtual Simulation. Private institutions that have an integrated/ interdisciplinary curriculum tend to use High Fidelity simulation more. The coordinators believe that Simulation of Specific Skills boosts, in addition to the cognitive and psychomotor attribute, the affective attribute; it is not in the nature of this modality to develop this attribute. As for Standardized Patient and Virtual Reality modalities, it is not possible to state that there is an understanding that they have the potential to boost the affective attribute. It is also not possible to state that there is an understanding that Virtual Reality can mobilize the cognitive attribute.

It is important that the managers of undergraduate courses are made aware and take ownership of the elements that permeate simulation, in order to prepare a favorable environment for its implementation.

\section{REFERENCES}

1. Cazañas EF. Desvelando o uso da simulação nos cursos de graduação de Enfermagem do Brasil. [Tese] Universidade do Estado de São Paulo [Internet]. 2020[cited 2020 Apr 24]. 106 f Available from: https://repositorio.unesp.br/bitstream/handle/11449/192404/caza\%c3\%b1as_ef_dr_ bot_par.pdf?isAllowed=y\&sequence $=5$

2. Makuch DMV, Zagonel IPS. Pedagogical approach in the implementation of curriculum programs in nurse training. Rev Esc Anna Nery. 2017;21(4):e20170025. https://doi.org/10.1590/2177-9465-ean-2017-0025

3. Tonhom SFR, Moraes MAA, Pinheiro OL. Nurse's training centred on professional practice: perception of students and professors. Rev Gaúcha Enferm. 2016;37(4):e63782. https://doi.org/10.1590/1983-1447.2016.04.63782

4. Martini JG, Massaroli A, Lazzari DD, Luz JHd. Currículos de cursos de graduação em enfermagem: revisão integrativa de literatura. Rev Pesq Cuid Fundam. 2017;9(1):265-72. https://doi.org/10.9789/2175-5361.2017.v9i1.265-272

5. Costa RRO, Medeiros SM, Vitor AF, Lira ALBC, Martins CA, Araújo MS. Tipos e finalidade da simulação no ensino de graduação em enfermagem: revisão integrativa da literatura. Rev Baiana Enferm. 2016;30(3):1-11. https://doi.org/10.18471/rbe.v30i3.16589

6. Brandão CFS, Collares CF, Marin HF. A simulação realística como ferramenta educacional para estudantes de medicina. Sci Med. 2014;24(2):18792. https://doi.org/10.15448/1980-6108.2014.2.16189

7. Miller GE. The Assessment of clinical skills competence performance. Acad Med. 1990;65(9):S63-S7. https://doi.org/10.1097/00001888-199009000-00045

8. World Health Organization (WHO). Multi-professional patiente safety curriculum guide[Internet]. 2011 [cited 2018 Jan 20]. Available from: http://apps.who.int/iris/bitstream/10665/44641/1/9789241501958_eng.pdf

9. Oliveira SN, Prado ML, Kempfer SS. Utilização da simulação no ensino da enfermagem: revisão integrativa. Rev Mineira Enferm. 2016;18(2). https://doi.org/10.5935/1415-2762.20140036

10. Moraes MAA, Tonhom SFR, Hafner MLMB, Gomes R. (Orgs.). Avaliação nos cursos de medicina e enfermagem: perspectivas e desafios. Curitiba: Editora CRV; 2012. 227 p. 
11. Silva JLG, Oliveira-Kumakura ARS. Simulação clínica para ensino da assistência ao paciente com ferida. Rev Bras Enferm. 2018;71(Suppl 4):178590. https://doi.org/10.1590/0034-7167-2017-0170

12. Waterkemper R, Prado ML. Estratégias de ensino-aprendizagem em cursos de graduação em Enfermagem. Av Enferm [Internet]. 2011 [cited 2019 May 30];29(2). Available from: https://revistas.unal.edu.co/index.php/avenferm/article/view/35793/36517

13. Kunst EL, Henderson A, Johnston ANB. A scoping review of the use and contribution of simulation in Australian undergraduate nurse education. Clin Simul Nurs. 2018;19:17-29. https://doi.org/10.1016/j.ecns.2018.03.003

14. Cant RP, Cooper SJ. Use of simulation-based learning in undergraduate nurse education: an umbrella systematic review. Nurse Educ Today. 2017;49:63-71. https://doi.org/10.1016/j.nedt.2016.11.015

15. Ministério da Saúde (BR). Conselho Nacional de Saúde. Resolução $n^{\circ} 466$, de 12 de dezembro de 2012. Aprova as diretrizes e normas regulamentadoras de pesquisas envolvendo seres humanos [Internet]. Diário Oficial da União: República Federativa do Brasil; 2013 [cited 2018 Aug 14]. Available from: http://bvsms.saude.gov.br/bvs/saudelegis/cns/2013/res0466_12_12_2012.html

16. Polit DF, Beck CT, Hungler BP. Fundamentos de Pesquisa em Enfermagem. Métodos, avaliação e utilização. Porto Alegre: Artmed, 2011. 487p.

17. STROBE Statement. Strengthening the reporting of observational studies in epidemiology. Strobe checklists: version 4 [Internet]. Berna: University of Bern; 2007 [cited 2018 Aug 20]. Available from: http://www.strobe-statement.org/index.php?id=available-checklists

18. Ministério da Educação (BR). Portal e-MEC [Internet]. Brasília (DF): Ministério da Educação; 2016. [cited 2016 Nov 2]. Available from: http:// emec.mec.gov.br/

19. Instituto Nacional de Estudos e Pesquisas Educacionais Anísio Teixeira. Nota Técnica Daes/Inep n 58/2015. Cálculo do Conceito Preliminar de Curso [Internet]. 2014 [cited 2018 May 29]. Available from: http://www.ufrgs.br/sai/avaliacao-externa/nacional/arquivos_nacional/nota\%20 tecnica\%20calculo\%20cpc\%20igc.pdf

20. Vieira S. Bioestatística: tópicos avançados. 3 ed. Rio de Janeiro: Elsevier; 2011. 288 p.

21. Dias MSA, Silva LMS, Silva LCC, Silva AV, Torres RAM, Brito MCC. Characterization of undergraduate nursing courses according to the National Student Performance Exam. Rev Bras Enferm. 2016;69(2):352-8. https://doi.org/10.1590/0034- 7167.2016690222i

22. Matsumara ESS, França AS, Alves LMF, Silveira MKS, Sousa Jr AS, Cunha KC. Spacial distribution of nursing graduate courses. Rev Enferm UFPE. 2018;12(12):3271-8. https://doi.org/10.5205/1981-8963-v12i12a236270p3271-3278-2018 Portuguese.

23. Erdmann AL, Fernandes JD, Teixeira GA. Panorama da educação em enfermagem no Brasil: graduação e pós-graduação. Rev Enferm Foco [Internet]. 2011 [cited 2018 May 28];2(supl):89-93. Available from: http://revista.cofen.gov.br/index.php/enfermagem/article/view/91/76

24. Nogueira VO. Competências do enfermeiro coordenador de cursos de graduação em enfermagem: um estudo paulista [Dissertação]. São Paulo (SP): Escola de Paulista de Enfermagem; 2015. 212 p.

25. Oliveira NV, Kowal OC, Isabel C. Formação e experiência profissional na coordenação de cursos de graduação em enfermagem. Rev Tesela [Internet]. 2018 [cited 2018 May 29]; 1-23. Available from: http://www.index-f.com/tesela/ts23/ts11685.php

26. Amaral NC. A educação superior brasileira: dilemas, desafios e comparações com os países da OCDE e do BRICS. Rev Bras Educ. 2016;21(66):717-736. doi: 10.1590/S1413-24782016216637.

27. Instituto Nacional de Estudos e Pesquisas Educacionais Anísio Teixeira. Censo da Educação Superior [Internet] Brasília, DF; 2018. [cited 2019 Oct 10] Available from: http://portal.inep.gov.br/web/guest/censo-da-educacao-superior

28. Presidência da República (BR). Lei n. 13.005, de 25 de junho de 2014. Aprova o Plano Nacional de Educação e dá outras providências[Internet]. Brasília, DF: 2014[cited 2019 Oct 10]. Available from: http://pne.mec.gov.br/18-planos-subnacionais-de-educacao/543-plano-nacional-de-educacao-lei-n-13-005-2014

29. Pinto AAM, Marin MJS, Otani MAP, Tonhom SFR. Avanços e desafios da reformulação curricular em enfermagem sob distintas perspectivas. Atas CIAIQ-Investigação Qualitativa em Saúde [Internet]. 2018 [cited 2018 May 29];2:451-61.Available from: https://proceedings.ciaiq.org/index.php/ ciaiq2018/article/download/1808/1761/

30. Varga CRR, Almeida, VC, Germano, CMR, Melo, DG, Chachá, SGF, Souto, BGA, et al. Relato de experiência: o uso de simulações no processo de ensino-aprendizagem em medicina. Rev Bras Educ Med. 2009;33(2):291-97. https://doi.org/10.1590/S0100-55022009000200018

31. Costa FJG, Aguiar ARC, Silva Araújo ALL, Basílio ABS, Costa RRO, Melo PD, et al. Práticas contemporâneas do ensino em saúde: reflexões sobre a implantação de um centro de simulação em uma universidade privada. Rev Bras Pesq Saúde[Internet]. 2013[cited 2018 May 29];15(3):85-90. Available from: http://www.periodicos.ufes.br/RBPS/article/viewFile/6330/4664

32. Ribeiro ECO, Lima VV. Competências profissionais e mudanças na formação. Rev Olho Mágico. 2003[cited 2019 Oct 8];10(2);47-52. Available from: http://www.aedmoodle.ufpa.br/pluginfile.php/177092/mod_folder/content/0/Ribeiro_Competencias_Profissionais_e_Mudancas_na_ Formacao.pdf?forcedownload=1

33. Iglesias AG, Pazin-Filho A. Emprego de Simulações no ensino e na avaliação. Rev Med (Ribeirão Preto). 2015;48 (3):233-40. https://doi. org/10.11606/issn.2176-7262.v48i3p233-240

34. Vieira RQ, Caverni LM. Manequim no laboratório de enfermagem: condições favoráveis à fidelidade de simulação. Rev Norte Mineira Enferm [Internet]. 2014 [cited 2018 May 29];3(2):47-63. Available from: https://www.periodicos.unimontes.br/index.php/renome/article/view/2506

35. Hunter LA. Debriefing and feedback in the current healthcare environment. J Perinat Neonat Nurs. 2016;30(3):174-78. https://doi.org/10.1097/ jpn.0000000000000173

36. Moraes MAA, Angeli AO. Desempenho dos pacientes simulados no exercício de avaliação da prática profissional. Rev Saúde. 2016;42(2):167-74. https://doi.org/10.5902/2236583421692 
37. Al-Ghareeb, AZ, Cooper SJ. (2016). Barriers and enablers to the use of high-fidelity patient simulation manikins in nurse education: an integrative review. Nurse Educ Today. 2016;36:281-86. https://doi.org/10.1016/j.nedt.2015.08.005

38. Domingues NA, Tibes CM, Dias JD, Westin UM, Zem-Mascarenhas SH, Fonseca LMM. Simulação virtual por computador no ensino de enfermagem: relato de experiência. Rev Enferm UFPI [Internet]. 2017[cited 2019 Sep 27];6(4):70-4. Available from: https://ojs.ufpi.br/index.php/ reufpi/article/view/6174/pdf

39. Kaneko RMU, Couto TB, Coelho MM, Taneno AK, Barduzzi NN, Barreto JKS, et al. Simulação in Situ, uma Metodologia de Treinamento Multidisciplinar para Identificar Oportunidades de Melhoria na Segurança do Paciente em uma Unidade de Alto Risco. Rev Bras Educ Med.2015:39(2):286-93. https://doi.org/10.1590/1981-52712015v39n2e00242014

40. Calliyeris V, Roble GLE, Costa C, Souza WS. Pesquisa via internet como técnica de coleta de dados: um balanço da literatura e os principais desafios para sua utilização. Rev Bras Mark. 2015;14(4):479-91. https://doi.org/10.5585/remark.v14i4.2867

41. Freitas $\mathrm{H}$, Janissek-Muniz R, Moscarola J. Uso da Internet no processo de pesquisa e análise de dados. Associação Nacional de Empresas de Pesquisa [Internet]. 2004 [cited 2019 Sep 27]:1-13. Available from: http://hdl.handle.net/10183/4801 